\title{
PENGARUH LANSEKAP TERHADAP PERKEMBANGAN PERMUKIMAN DI KAWASAN KALISARI SEMARANG
}

\author{
Arnis Rochma Harani ${ }^{\text {a1) }}$, Anityas Dian Susantib2) ${ }^{\text {2) Hermin Werdiningsih }}{ }^{\text {a3) }}$ \\ ${ }^{a}$ Universitas Diponegoro \\ Jl. Prof. Soedarto, S.H., Tembalang Semarang \\ ${ }^{\mathrm{b}}$ Universitas Pandanaran \\ Jl. Banjarsari Barat No.1 Semarang \\ Email $^{1)}$ : arnis.rochma@gmail.com \\ Email $^{2)}$ : tyas@unpand.ac.id \\ Email $^{3)}$ : hwerdiningsih@yahoo.com
}

\begin{abstract}
ABSTRAK
Menurut Forman \& Godron (1986) lansekap adalah suatu lahan heterogen dengan luasan tertentu yang terdiri dari kumpulan ekosistem yang saling berinteraksi, kumpulan tersebut dapat ditemukan secara berulang dalam suatu wilayah dengan bentuk yang sama. Sedangkan pengertian lain menyatakan lansekap adalah penafsiran visual atas susunan tanah (wikipedia). Semarang merupakan kota yang memiliki lansekap yang sangat menarik. Wilayah kota Semarang bertansis membuat beberapa wilayah memiliki perbedaan kondisi lansekap. Ada yang berkontur tajam, ada yang pada wilayah datar dan ada yang terletak ditepi pantai. Salah satu wilayah yang berada pada posisi bertransis tajam adalah kawasan permukiman kalisari, selain itu lokasinya berada di tengah pusat kota Semarang. Sejak dahulu kala kawasan ini merupakan kawasan permukiman yang padat, semakin lama perkembangan permukiman diwilayah ini pesat. Pada kondisi lansekap yang sangat curam ini pasti memiliki pengaruh terhadap pola permukimannya, sehingga hal ini sangat menarik untuk diteliti. Metode yang akan digunakan adalah metode kualitatif deskriptif yang akan mengacu pada grand concept yang telah disusun. Teori lansekap dan permukiman menjadi acuan dalam pencarian data. Kepekaan peneliti untuk mencari data dilapangan menjadi sesuatu yang penting. Analisis terhadap temuan-temuan dilapangan diperlukan yang tajam, sehingga akan perpengaruh terhadap hasil. Dari pengaruh bentuk lansekap terhadap tata ruang permukiman yang ada didaerah Kalisari, diperoleh temuan berupa terdapat ruang bersama diantara perbedaan level lantai pada rumah tinggal masyarakat setempat, .dapat berupa teras rumah, dan ruang jemur. Sementara sirkulasi jalan merupakan tempat untuk bersosialisasi dan pusat kegiatan berada di masjid yang lokasinya ada ditengah-tengah permukiman.
\end{abstract}

Keyword : Lansekap, Tata Ruang, Permukiman, Kalisari

\section{PENDAHULUAN}

Menurut Forman \& Godron (1986) lansekap adalah suatu lahan heterogen dengan luasan tertentu yang terdiri dari kumpulan ekosistem yang saling berinteraksi, kumpulan tersebut dapat ditemukan secara berulang dalam suatu wilayah dengan bentuk yang sama. Lansekap juga diartikan sebagai bentang alam (Laurie, 1975). Sehingga dapat disimpulkan bahwa lansekap merupakan suatu bentuk alam yang ada di bumi yang terdiri dari beberapa ekosisten yang saling berinteraksi.

Bentuk lansekap tentunya beraneka ragam. Semarang merupaka kota yang memiliki lansekap sangat menarik. Terbentang dari wilayah pantai hingga pegunungan, lansekap kota Semarang bertransis dan membentuk beberapa wilayah yang terkenal dengan Semarang atas dan Semarang bawah. Beberapa 
kota di Indonesia memiliki ciri lansekap yang hampir sama, namun Semarang merupakan kota yang paling menarik untuk bentukan lansekapnya. Salah satu kawasan yang memiliki lansekap menarik adalah kawasan kalisari Semarang, lokasinya berada di pusat kota Semarang, tidak jauh dari monumen Tugu muda yang dikenal sebagai landmark Semarang. Kawasan ini memiliki bentuk lansekap yang bertransis tajam, berupa bukit. Namun saat ini kawasan ini menjadi permukiman yang padat penduduk. Hal ini dipengaruhi oleh jumlah penduduk di kota Semarang yang semakin meningkat ditiap tahunnya, membuat kota Semarang menjadi padat, salah satu dampaknya adalah meningkatnya kawasan permukiman.

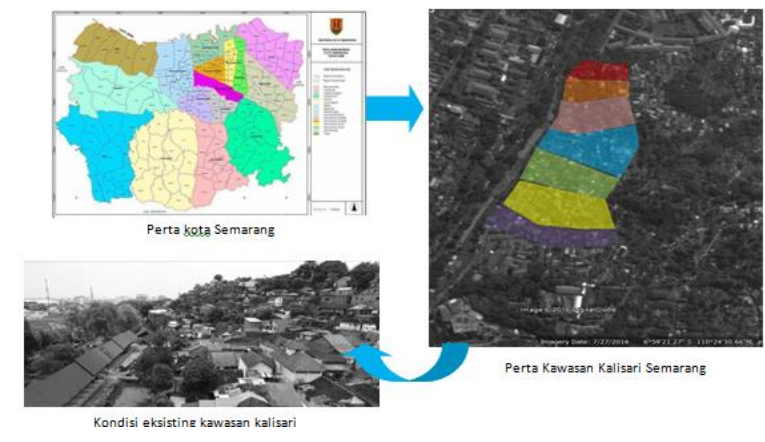

Gambar 1. Lokasi penelitian (Kalisari Semarang)

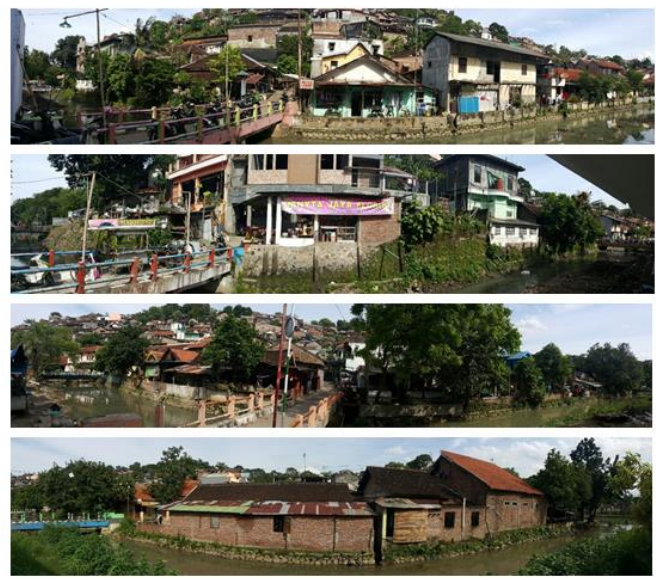

Gambar 2. Kondisi eksisting (Kalisari Semarang)

1992 tentang Perumahan dan Pemukiman, pemukiman atau permukiman adalah bagian dari lingkungan hidup di luar kawasan lindung, baik yang berupa kawasan perkotaan maupun pedesaan yang berfungsi sebagai lingkungan tempat tinggal atau lingkungan hunian dan tempat kegiatan yang mendukung peri kehidupan dan penghidupan. Permukiman di kawasan Kalisari yang semakin meningkat tiap tahunnya, dengan demikian wilayahnya semakin padat. Hal ini sangat berdampak bagi tata ruang pemukiman dikawasan tersebut. Dengan kondisi lansekap yang berada di bukit, memiliki tingkat kepadatan yang tinggi, serta lokasinya yang berada di tengah kota menjadi menarik.

\section{METODOLOGI}

Perkembangan di kawasan Kalisari menjadi kawasan padat penduduk mengakibatkan meningkatnya permukiman, dengan bentuk lansekap yang berbukit dan bertransis tajam tentunya menjadi salah satu hal yang menarik untuk dilihat pengaruhnya terhadap tata ruang permukiman yang terbentuk. Penelitian ini bertujuan untuk mengetahui pengaruh bentuk lansekap di kawasan kalisari terhadap tata ruang permukiman yang terbentuk.

\section{HASIL DAN PEMBAHASAN} Analisis Bentuk Lansekap Kalisari Semarang Kota Semarang terkenal akan lansekapnya yang memiliki cirri khas khusus yaitu terdiri dari wilayah pantai, dataran rendah, dataran tinggi dan pegunungan. Ini menjadi sesuatu nilai plus di kota ini. Karena kondisinya yang, maka terdapat wilayah-wilayah yang berada di bukit-bukit.Perkembangan permukiman di kota Semarang maju sangat pesat, baik itu di kawasan pantai hingga di kawasan pegunungan. Perkembangan permukiman juga merambah pada lokasi-lokasi yang berbukit, salah satu permukiman kuno yang berada di bukit dengan lansekap menarik adalah kawasan Kalisari Semarang.

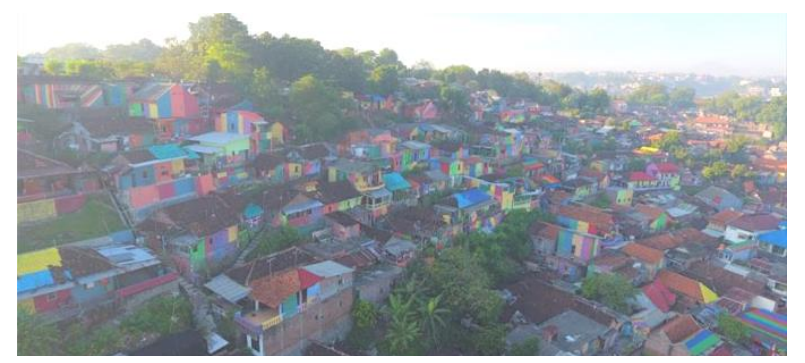

Gambar 3. Bentuk lansekap permukiman Kalisari Semarang 
Menurut sejarahnya, laut di kota Semarang sampai pada Gunung Brintik, Gunung Brintik merupakan perbukitan yang saat ini lebih dikenal dengan nama Kalisari, pada Gunung Brintik tersebut awalmula adanya permukiman yang berbatasan dengan laut dijamannya. Garis pantai semakin lama semakin mundur hingga saat ini kawasan ini menjadi dataran rendah dan memiliki bukit dan dikenal dengan permukiman Kalisari.

Pemukiman Kalisari yang berada pada lansekap yang berbukit ini semakin tahun semakin padat, dan mengakibatkan kekumuhan karena banyaknya yang tinggal disana. Serta lokasinya yang dekat dengan sungai. Dilihat dari lokasinya, permukiman ini berada tepat di pusatkota Semarang, berbatasan langsung dengan Tugu Muda yang merupakan icon dari Kota Semarang. Hal ini menjadikan kawasan ini sangat buruk dari segi kualitas visual. Dengan permukiman bertransis sangat mudah dilihat darimana saja, hal ini menimbulkan serial vision yang buruk bagi pengguna jalan.

Hal menarik lainnya adalah kawasan Kalisari ini bias menembus kebukit Bergota dibaliknya yang terkenal sebagai tempat pemakaman terbesar di kota Semarang. Selain pemakaman, disana juga terdapat permukiman dan pasar. Sehingga jika dijelaskan keragaman lansekap di Kalisari ini sangatlah unik dan menarik.

\section{Unsur-unsur pembentuk struktur tata ruang kotamenurut doxiadis (1968):}

1. Individu manusia (Antropos) dan masyarakat (Society) Di kota besar dengan kepadatan tinggi, terdapat perbedaan komposisi umur dan jenis kelamin, dalam struktur pekerjaan, dalam pembagian tenaga buruh dan struktur social. Hal ini memaksa manusia untuk mengembangkan karakteristik yang berbeda sebagai individual, kelompok, unit dan komunitas. Pada permukiman Kalisari Semarang, penduduknya $72 \%$ bekerja sebagai pegawai swasta dan buruh. Keberadaan kawasan perdagangan yang ada disisi depan permukiman tidak terkait dengan permukiman
Kalisari. Justru pengguna kawasan perdagangan tersebut adalah pendatang. Sedangkan warga Kalisari sebagian besar bekerja diluar permukiman. Dari latar belakang individu tersebut maka tentunya berpengaruh terhadap bentuk permukiman. Yaitu permukiman hanya ramai ketika sore hari, dikarenakan pada siang hari masyarakatnya bekerja. Sehingga sirkulasi di kawasan permukiman ini menjadi padat ketika pukul 15.00-19.00 WIB.

2. Ruang kehidupan (Shells) Ruang kehidupan dari perumahan perkotaan memiliki banyak karakteristik meskipun ukurannya bervariasi. Semakin besar ukuran perumahan, semakin internasional karakteristiknya; sementara semakin kecil ukurannya semakin dipengaruhi oleh faktor-faktor lokal. Semakin hari kepadatan kampong Kalisari semakin tinggi. Dari hasil analisis diperoleh data bahwa setiap rumah tinggal dihuni 1 sampai 3 kepala keluarga. Hal ini disebabkan adanya pernikahan dan anak yang telah menikah tidak keluar dari rumah, justru berkumpul dengan orang tuanya. Dari beberapa kasus ini tentunya muncul fenomena pembagian ruang didalam rumah. Dalam kasus kawasan, makadampaknya adalah semakin padat. Ruang-ruang permukiman seperti ruang komunal yang terbentuk adalah jalan yang difungsikan sebagai sirkulasi berubah menjadi ruang komunal, tempat bermain, tempat berkumpul bahkan ketika ada acara jalan digunakan dan tidak ada komplaain dari warga. Karena mereka beranggapan bahwa jalan adalah area bersama yang dapat digunakan secara bersama. 


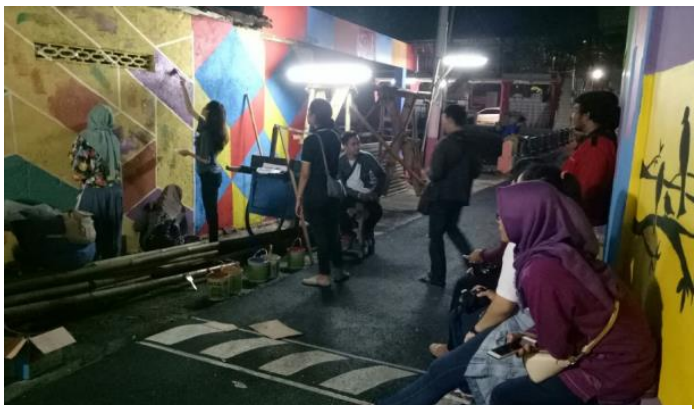

Gambar 4. Jalan digunakansebagai area berkumpul (ruang komunal)

3. Fenomena lain adalan adanya ruang komunal yang terbentuk akibat bertemunya rumah satu dan lainnya, terkait dengan bentuk lansekap yang bertransis dan tinggi. Rumah-rumah bagian atas yang terdapat teras dan bertemu dengan ruang jemur di lantai atas rumah yang lokasinya dibawahnya, maka akan muncul ruang bersama sebagai tempat berkumpul.

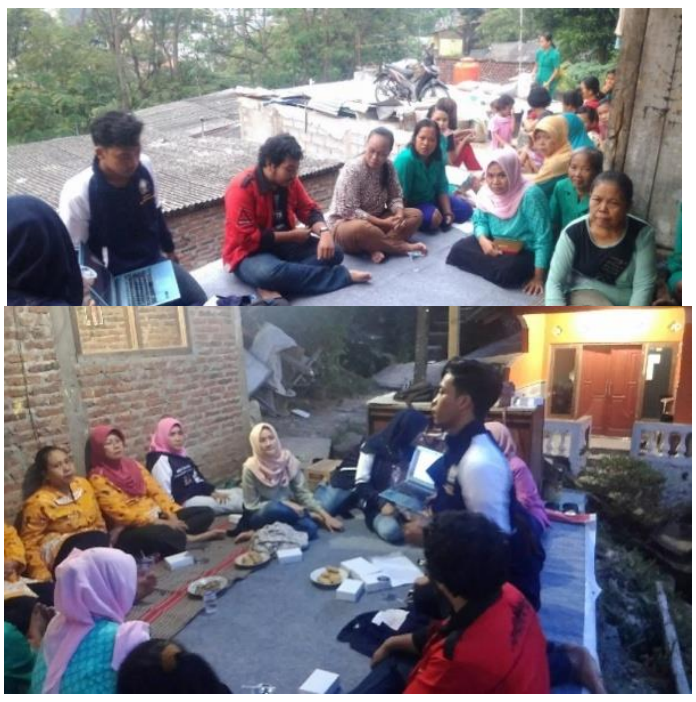

Gambar 5. Teras dan tempat jemur sebagai tempat berkumpul (ruang komunal)

4. Jaringan (Network) Salah satu cara paling mendasar untuk menggambarkan struktur permukiman adalah berhubungan dengan jaringan dan terutama sistem sirkulasi - jalur transportasi dan titik-titik pertemuan (nodal point). Pada kampung Kalisari memiliki keunikan, yaitu lebar jalannya hanya 1,5-2 meter. Jalan yang terbentuk merupakan jaringan yang menghubungkan dunia luar dengan kampung tersebut. Ada beberapa akses utama menuju kampung pelangi, orientasi masuknya dari pasar bunga. Jaringan jalan yang kecil dan terbatas merupakan cirri khas dari permukiman tersebut yang terbentuk dari lansekap yang bertransis dan ekstrim. Transportasi yang biasa masuk ke kampung ini adalah motor beroda dua. Untuk mobil tidak dapat masuk karena tidak ada akses yang mendukung.

5. Alam (Nature) Keadaan permukiman perkotaan berbeda dengan permukiman pedesaan. Lansekap yang ada biasanya lebih luas dan berlokasi di daerah dataran, dekat dengan danau, sungai atau laut dan dekat dengan rute transportasi. Keadaan permukiman Kalisari sangat unik, yaitu permukiman terbentuk di lansekap yang ekstrim, darisegi view from site memiliki kelebihanya itu dapat melihat lebih luas pemandangan ke kota Semarang, terutama yang dapat lokasi paling atas, sedangkan view to site memiliki kelebihan lain, yaitu permukiman dapat menjadi sebuah visual kota yang positive saatinikarena kampung Kalisari telah di kenal dengan kampung pelangi yang berwarna. Namun dahulu permukiman ini menjadi nilai negatif karena sangat kumuh.

Menurut Sastra dan Marlina (2005) proses pembentukan suatu permukiman dapat dilihat dari pemahaman tentang adanya realitas hubungan antar masing-masing tahapan dari proses pembentukan permukiman tersebut. Diagram proses terbentuknya permukiman sebagai berikut :

- Alam sebagai wadah $\rightarrow$ ada manusia $\rightarrow$ membentuk kelompok sosial yang berfungsi sebagai masyarakat.

- Kelompok sosial membutuhkan perlindungan $\rightarrow$ membuat bangunan $\rightarrow$ menjadi lingkungan besar dan kompleks $\rightarrow$ terbentuk Networks $\rightarrow$ terbentuk permukiman (Human Settlements). 
Pada permukiman Kalisari, alam (bentuk lansekap) mempengaruhi bentuk permukiman, sehingga alam yang ada disana menjadi faktor terpenting dalam proses terbentuknya permukimannya.

\section{SIMPULAN}

Dari analisis diatas dapat diperoleh kesimpulan sebagai berikut:

1. Pengaruh lansekap di permukiman kalisari sangat besar, dapat dilihat dari temuan yaitu terbentuknya ruang-ruang komunal diantara rumah satu dan lainnya, sehingga dapat dimanfaatkan secara bersama

2. Karena lokasi berbukit, maka jaringan jalan disini tidak dapat dilalui oleh mobil, hanya kendaraan roda dua.

3. Karena begitu padatnya, maka masyarakat menggunakan jalan sebagai area berkumpul dan berinteraksi.

\section{DAFTAR PUSTAKA}

Doxiadis, C.A., 1968, An Introduction To The Science Of Human Settlements Ekistics, Hutchinson of London, London.

Forman, R.T.T. and Gordon, M., 1986, Landscape Ecologi, John Wiley \& Sons.Inc., New York.

Undang-undang No 4 tahun 1992 tentang Perumahan dan Pemukiman

Laurie, M., 1975, An Introduction to Landscape Architecture, American Plublisher.

Sastra M, S. dan Marlina., E., 2005, Perencanaan dan Pengembangan Perumahan, Andi Offset, Yogyakarta. 